\title{
Hafnium isotopes in zircons track the changing sources for the Late Cretaceous magmatism in Eastern Srednogorie, Bulgaria
}

\section{Приложение на хафниевите изотопи в циркони за проследяване на промените в източниците на кьснокредния магматизьм в Източното Средногорие, България}

\author{
Svetoslav Georgiev ${ }^{1,2}$ \\ Светослав Георгиев ${ }^{1,2}$ \\ ${ }^{1}$ Institute of Geochemistry and Petrology, ETH Zurich, Clausiusstrasse 25, CH-8092 Zurich, Switzerland \\ ${ }^{2}$ AIRIE Program, Colorado State University, Fort Collins, 80523-1482 CO, USA; E-mail: georgiev@colostate.edu
}

\begin{abstract}
We present new Hf isotopic data of magmatic zircons from the Eastern Srednogorie zone. The data outline two clear temporal trends: rising initial $\varepsilon H f$ from the initiation of the magmatism at 25 Ma to 81 Ma, followed by a rapid decline in the initial $\varepsilon \mathrm{Hf}$ in the $81-78 \mathrm{Ma}$ time period. The first trend highlights the increasing participation of mantle melts in the formation of magmatic products in the East Balkan and Strandzha regions, which is likely dictated by the southward retreat of the subducting slab. This trend is also evident in published Hf isotopic data on zircons from Central Srednogorie zone. The second trend of rapidly decreasing initial $\varepsilon \mathrm{Hf}$ of zircons is interpreted to reflect increased proportion of lower crustal melts in an intra-arc rift extensional environment (the Yambol-Burgas region) between 81 and $78 \mathrm{Ma}$; this trend is not observed in the Central Srednogorie zone.
\end{abstract}

Keywords: Hf isotopes, $\varepsilon$ Hf, MC-ICPMS, East Balkan, Strandzha.

\section{Introduction}

Eastern Srednogorie zone is the widest segment of the extensive Late Cretaceous magmatic arc in SE Europe. Abundant intrusive and extrusive magmatic products are exposed in three main tectonomagmatic regions within Eastern Srednogorie, from north to south: East Balkan, Yambol-Burgas and Strandzha (Georgiev et al., 2006). Recent petrological and geochronological studies offer a geodynamic model for the Cretaceous evolution of this zone (Georgiev et al., 2009, 2012). The earliest stage of normal arc magmatism at 95.4 Ma (Georgiev et al., 2021) produced limited calc-alkaline to high-K, basaltic to andesitic sub-volcanic bodies and lava flows in the East Balkan. A southward shift of the igneous activity is delineated by $87-86 \mathrm{Ma}$ old tholeiitic to calc-alkaline intrusions and voluminous 81-78 Ma old gabbroic to granitic intrusions with predominantly calc-alkaline to high-K composition throughout the Strandzha region. Extension associated with the opening of the Black Sea back-arc basin led to the formation of an intra-arc rift in the Yambol-Burgas region at $\sim 81-78 \mathrm{Ma}$, which hosts large volumes of shoshonitic to ultrapotassic, mostly basaltic to intermediate magmas and subordinated intrusions, including primitive lavas and melt inclusions with ankaramitic composition (Marchev et al., 2009). Trace element and $\mathrm{Sr}$ and $\mathrm{Pb}$ wholerock isotopic data suggest increased involvement of mantle sources during this stage (Georgiev et al., 2009). However, the changing proportion of mantle source within the Eastern Srednogorie zone during the Late Cretaceous, and broader-scale comparisons to coeval magmatism in the neighbouring Central Srednogorie zone are not fully understood. Here, we present new Hf isotopic data on zircons from the East Srednogorie zone that were previously 


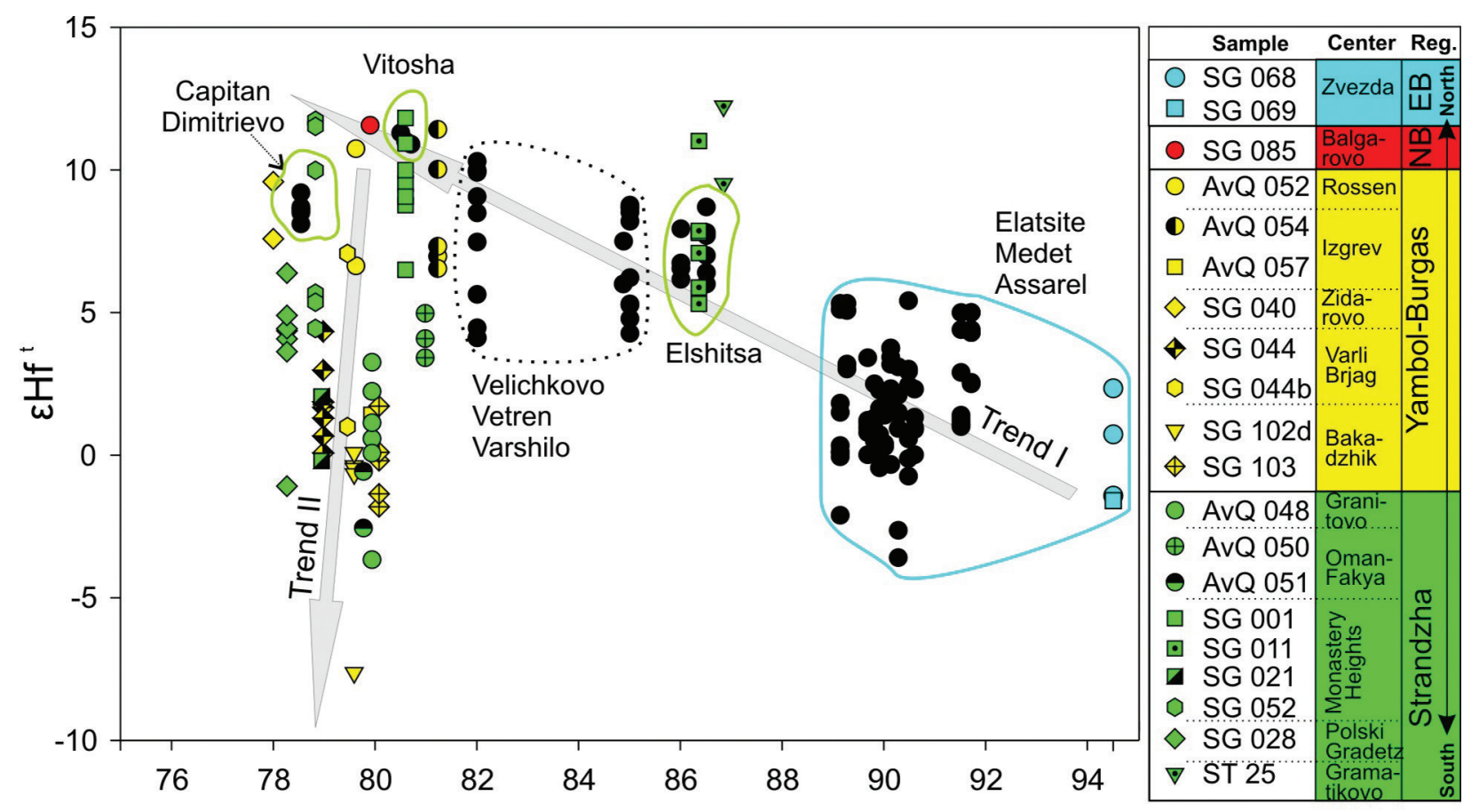

Age, Ma

Fig. 1. Initial $\varepsilon \mathrm{Hf}\left(\varepsilon \mathrm{Hf}^{\mathrm{t}}\right)$ of zircons from the 4 magmatic regions of Eastern Srednogorie vs. the age of the rock (sample names and ages from Georgiev, 2008). The geochemical characteristics of the North Burgas (NB) region suggest that it should be considered as part of the Yambol-Burgas (YB) region (Georgiev et al., 2006). The fields of different centers from Central Srednogorie zone are shown for comparison, together with individual zircon age and $\varepsilon \mathrm{Hf}^{\mathrm{t}}$ (black circles, data from von Quadt et al., 2002, 2005; Peytcheva et al., 2009). Arrows indicate major trends discussed in the text.

dated by $\mathrm{U}-\mathrm{Pb}$ methods. Our new data characterize the main sources involved in the Eastern Srednogorie magmatism, track their changing proportion throughout the Late Cretaceous, and facilitate improved comparisons with the magmatism in the Central Srednogorie zone.

\section{Samples and methods}

Magmatic rocks from the tree main regions were collected as part of previous geochemical and geochronological studies. Hafnium isotope ratios in zircons were measured in ETH-Zurich on a Nu500 MC-ICPMS using established techniques. The samples were introduced into the ICP either as a solution (for zircons previously dated by TIMS) or as laser-ablated material (for zircons previously dated by LA-ICPMS). The quality of the data was controlled by repeated analysis of the JMC-475 standard solution and zircons standards 91,500, Temora-2, Mud Tank and Monastery; measured Hf ratios agree with the published standard values. Typical analytical uncertainty was $\sim 0.3 \varepsilon \mathrm{Hf}$ units for the solution work, and $\sim 0.5 \mathrm{\varepsilon Hf}$ and for the laser ablation analyses.

\section{Results}

Our results are graphically summarized on Fig. 1, which shows the initial $\varepsilon \mathrm{Hf}$ of individual zircons $\left(\varepsilon \mathrm{Hf}^{\mathrm{l}}\right.$ at the time of crystallization) from Eastern Srednogorie. The Hf isotopes of most Upper Cretaceous zircons at their time of crystallization range from $\varepsilon \mathrm{Hf}^{\mathrm{t}}$ of +13 to $\varepsilon \mathrm{Hf}^{\mathrm{t}}$ of -3 , indicating the involvement of contrasting geochemical sources in the genesis of the magmas. The initial $\varepsilon \mathrm{Hf}$ of zircons $\left(\varepsilon H f^{\mathfrak{l}}\right)$ reflects the $\varepsilon \mathrm{Hf}$ of the magma at the time of crystallization, which in turn is controlled by the relative contribution of crustal sources (low, negative $\varepsilon \mathrm{Hf}$ ) and depleted mantle sources (high, positive $\varepsilon \mathrm{Hf}$ ). In the Late Cretaceous, the mantle end-member had $\varepsilon \mathrm{Hf}$ of about +14 to +16 , whereas Variscan basement granitoids had negative $\varepsilon \mathrm{Hf}$ (estimated mean at -5 ; Georgiev, 2008). There is a clear temporal (and geographic) trend in the $\varepsilon \mathrm{Hf}^{\mathrm{t}}$ of Cretaceous zircons. The earliest (95.4 Ma) magmatic products in the northernmost East Balkan region have $\varepsilon \mathrm{Hf}^{\mathrm{l}}$ about 0 . These values suggest a mixed mantle-crust origin for the formation of East Balkan magmatism, which is not untypical for arc settings. The southward migration of the magma- 
tism with time into Strandzha region is accompanied by gradual increase of the $\varepsilon \mathrm{Hf}^{\mathrm{t}}$ to +5 to +8 in $\sim 86 \mathrm{Ma}$ intrusions and rises to +12 in 81 Ma rocks. This trend of increasing involvement of mantle sources is likely related to the southward retreat of the subducting slab, which facilitated the incursion of asthenospheric material into a widening mantle wedge. Similar trend of increasing mantle input with time is observed also in the adjacent Central Srednogorie zone. In contrast to Central Srednogorie, however, data from the Yambol-Burgas region and some of the youngest magmatism in the Strandzha region define a trend of rapid decrease of the $\mathrm{Hf}$ isotopes at ca. $80 \mathrm{Ma}$. Interestingly, the lowest $\varepsilon \mathrm{Hf}^{\mathrm{i}}$ (down to ca. -3 ) are recorded in samples with the least radiogenic $\mathrm{Sr}$ and $\mathrm{Pb}$ isotopes (Georgiev, 2008). Therefore, we suggest that the trend of decreasing Hf isotopes in the Yambol-Burgas region reflects substantial melting of lower crustal material in an extensional environment, as opposed to crustal contamination of mantle-derived magmas with mid- to upper crustal lithologies. Melting of the lower crust was likely facilitated by both subduction-related fluid fluxing and by the extensional regime established at $\sim 80 \mathrm{Ma}$ as an intra-arc rift (the Yambol-Burgas region).

Acknowledgements: The Hf isotope data were obtained as part of the author's $\mathrm{PhD}$ thesis at ETH Zurich supported by the Swiss National Science Foundation projects nos. 200020-100735, 200020 107955 and 200020-116693, Bulgaria.

\section{References}

Georgiev, S. 2008. Sources and Evolution of Late Cretaceous Magmatism in Eastern Srednogorie, Bulgaria: Constraints from Petrology, Isotope Geochemistry and Geochronology. PhD. Thesis, ETH Zurich, 270 p.; https://www.researchcollection.ethz.ch/handle/20.500.11850/15054.
Georgiev, S. V., A. von Quadt, I. Peytcheva, P. Marchev, C. A. Heinrich. 2006. Eastern Srednogorie - new geochemical data for lateral zonation of magmatism. - In: Proc. Bulg. Geol. Soc., Geosciences 2006. Sofia, 197-200.

Georgiev, S., P. Marchev, A. von Quadt, Ch. Heinrich, I. Peytcheva, P. Manetti. 2009. Origin of nepheline-normative high-K ankaramites and the evolution of Eastern Srednogorie zone, SE Europe. - J. Petrol., 50 (10), 1899-1933; https://doi.org/10.1093/petrology/egp056.

Georgiev, S., A. von Quadt, C. A. Heinrich, I. Peytcheva, P. Marchev. 2012. Time evolution of a rifted continental arc: Integrated ID-TIMS and LA-ICPMS study of magmatic zircons from the Eastern Srednogorie. - Lithos, 154, 53-67; https://doi.org/10.1016/j.lithos.2012.06.020.

Georgiev, S. V., Marchev, P., Jicha, B., Banushev, B., Raicheva, R., Peytcheva, I., von Quadt, A. 2021. ${ }^{40} \mathrm{Ar} /{ }^{39} \mathrm{Ar}$ age and petrology of magmatic rocks from East Balkan (Bulgaria) constrain the initiation of regional subduction in SE Europe. - Lithos, 308-309, 106302. https://doi. org/10.1016/j.lithos.2021.106302.

Peytcheva, I., A. von Quadt, F. Neubauer, M. Frank, R. Nedialkov, C. Heinrich, S. Strashimirov. 2009. U-Pb dating, Hf-isotope characteristics and trace-REE patterns of zircons from Medet porphyry copper deposit, Bulgaria: implications for timing, duration and sources of ore-bearing magmatism. - Mineral. and Petrol., 96, 19; https://doi. org/10.1007/s00710-009-0042-9.

Marchev, P., S. Georgiev, Z. Zajacz, P. Manetti, R. Raicheva, A. von Quad. 2009. High-K ankaramitic melt inclusions and lavas in the Upper Cretaceous Eastern Srednogorie continental arc: implications for the genesis of arc shoshonites. - Lithos, 113, 228-245; https://doi.org/10.1016/j.lithos.2009.03.014.

von Quadt, A., I. Peytcheva, B. Kamenov, L. Fanger, C. A. Heinrich, M. Frank. 2002. The Elatsite porphyry copper deposit in the Panagyurishte ore district, Srednogorie zone, Bulgaria: $\mathrm{U}-\mathrm{Pb}$ zircon geochronology and isotopegeochemical investigations of magmatism and ore genesis. - Geol. Soc., London, Special Public., 204 (1), 119-135; https://doi.org/10.1144/gsl.sp.2002.204.01.08.

von Quadt, A., I. Peytcheva, L. Fanger, C. Heinrich. 2005. The Elatsite porphyry $\mathrm{Cu}-\mathrm{Au}$ deposit, Bulgaria. Ore deposit: Lat. 42 degrees $45^{\prime} \mathrm{N}$, Long. 24 degrees $02^{\prime}$ E. - Ore Geol. Rev., 27, 128-129; https://doi.org/10.1016/j.oregeorev.2005.07.022. 